DOI: https://doi.org/10.31933/dijemss.v2i6

Received: 21 August 2021, Revised: 15 September 2021, Publish: 30 September 2021

\begin{tabular}{llr} 
& DIJEMSS \\
& DINASTI INTERNATIONAL JOURNAL \\
PINASTI & OF EDUCATION MANAGEMENT AND & https://dinastipub.org/DIJEMSS \\
PULISHER & SOCIAL SCIENCE & $08117401455 @$ \\
\hline
\end{tabular}

\title{
THE ROLE OF SOCIAL MEDIA THROUGHPROMOTIONAS ITS MEDIATING VARIABLE IN AFFECTING CONSUMERS' PURCHASE DECISIONS (RESEARCH ON SOCIAL MEDIA FOLLOWERS OF ESENAK BUBBLE TEA KARA WANG)
}

\author{
Abdul Jabbar ${ }^{1}$, Chaerudin Chaerudin ${ }^{2}$ \\ 1) Universitas Singaperbangsa Karawang, Karawang, Indonesia, 114abduljabbar@ gmail.com \\ 2) Universitas Singaperbangsa Karawang, Karawang, Indonesia, chaerudin18@ gmail.com
}

Corresponding Author: Abdul Jabbar

Abstract: Changes in spending style caused by economic progress are a phenomenon that should be learned so that business people will continue to keep up with recent developments, particularly on the marketing field along with technological advances, these marketing methods which start modernized by latest technology, just like social media is an example. This research aims to reveal the impact from social media with promotion as mediation on purchasing decisions at bubble tea store eSenak Karawang. The research method used was descriptive verification with a quantitative technique. The population in this research are the total number of eSenak followers with sample of 175 respondents. Data were evaluated through path analysis by multivariate data techniques to examined the hypothesis. The results of this research declared that social media has a positive affect on promotion, social media has no affect on purchasing decisions, promotions have an affect on purchasing decisions.

Keywords: Social Media, Promotion, Purchase Decision.

\section{INTRODUCTION}

Covid-19 pandemic which spread on the beginning of 2020 has become a serious issue and given huge impact in various sectors, include the economic sector. From this phenomenon, those businesses which engaged in food and beverage $(\mathrm{F} \& \mathrm{~B})$ services were affected, resulting in a decline in production of the F\&B industry (Rina, 2020). According to news reported by CNBC Indonesia (2020), the Indonesian Food and Beverage Entrepreneurs Association (GAPMMI) predicts that the decline in industrial growth of around 5\% from the previous year that will slow down to the slow pace of the economy in this field and ultimately affects the low purchasing power of the people.

Purchase power of the community, certainly, will greatly affects to MSME players whose most of their businesses in the F\&B sector were experienced decline between 40-70 percent (Putra, 2020). eSenak Karawang is one of the MSMEs which engaged in the F\&B sector whose experienced decline in income throughout 2020. It was recorded that within 12 
months, the monthly income decreased by almost $40 \%$. With these dynamics, surely, eSenak has to turned its brains harder so its business will continue to survive. One of the efforts that should be made by eSenak is promotion through social media.

Potential of social media today is very good, so it has a very recommended move to promote social media. According to the research by Holmes et al. (2020), Instagram and Facebook are one of the most visited social media platforms by users. Therefore, product promotion strategies through Social Media Paid and Social Media Organic become one of the keys in conducting promotions that are expected to be able to increase the customer purchasing decisions.

Diyatma \& Rahayu (2017) found that through social media speech, the message that conveyed will be widely spread in a very short time, which indirectly affects the minds of consumers to see the advertisement or product that we conveyed. While Khoiro et al. (2019) found that one of the tools in marketing that can be used by a company is through social media. Furthermore, research by Dewi (2018) found that sellers need to pay attention to promote products as well as possible, because consumers will take an attitude towards the advertising or evaluations in the form of positive or negative impressions relates to the product being promoted.

According to the phenomena which occured currently and the existing research gap, the researchers are interested in conducting research with title "The Role of Social Media through Promotion as its mediating variable in affecting Consumers' Purchase Decisions (Research on Social Media Followers of ESENAK BUBBLE TEA Karawang)”.

\section{THEORETICAL REVIEW}

\section{Purchase Decision}

Following Armstrong \& Kotler (2013) purchasing decisions is part of a larger buying process starts with the recognition of need sthrough the way we felt after making a purchase. Furthermore, we as marketers are required to know the entire purchase decision process such as problem identification, information search, alternative evaluation, purchase decision, and post-purchase evaluation (Armstrong et al., 2017). Tjiptono (2012) declared that consumer purchase decisions are affected by several indicators, namely: product choice, brand choice, distributor choice, purchase time, number of purchases and payment methods.

\section{Promotion}

In accordance with Tjiptono (2015) promotion is an element from the combine marketing which focuses on efforts to inform, persuade, and remind consumers of the company's brands and products. Meanwhile, Kotler \& Ketler (2016) argues that sales promotion is a short-term incentive to push the sale of products or services. Furthermore, Kotler \& Ketler (2016) also revealed that there are four indicators to measure promotion, such as sales promotion, advertising, public relations and direct marketing.

\section{Social Media}

Social media is a tool for interaction among people where they create, share, and exchange information and ideas in virtual communities and networks (Solomon, 2018). Meanwhile, Kotler \& Ketler (2016) stated social media as a means for consumers to share text, image, audio and video information with each other and with companies and conversely. 
According to Gunelius in Mileva \& Fauzi (2018), found that there are four social media marketing indicators, namely content creation, content sharing, connecting social networks and community building social webs.

\section{Theoretical Framework and Hypothesis}

Based on the theory and empirical data which mentioned above, the following hypothesis that can be drawn such as:

H1: There is affect caused by Social Media to Promotion

H2: There is affect caused by Social Media to Purchase Decisions

H3: There is affect caused by Promotion to Purchase Decision

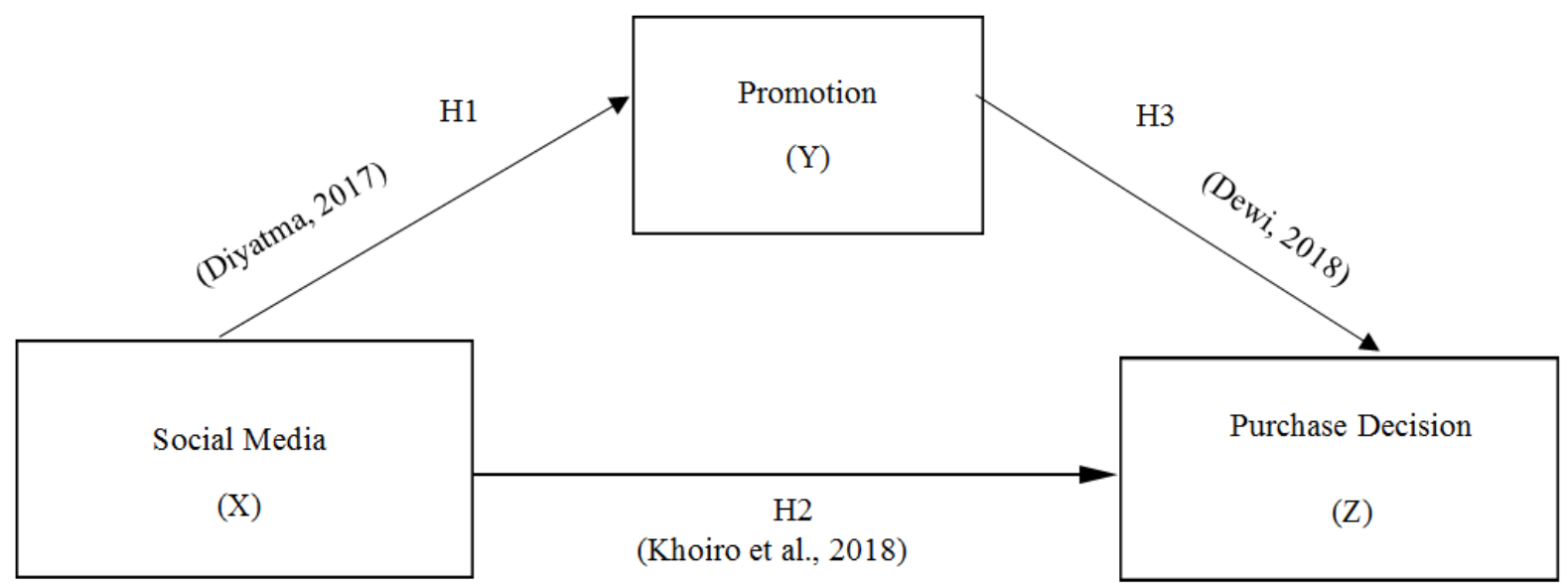

Figure 1. Theoretical Framework

\section{RESEARCH METHODS}

The kind method that used in this research was descriptive verification with quantitative method. In this research, the three variables are used, with one independent variable (social media), one mediating variable (promotion) and one dependent variable (purchase decision). The research population was the total followers of eSenak bubble tea Karawang with total sample of 175 respondents ( $5 \mathrm{x}$ indicators) which taken through a simple random sampling technique. Data collection methods used questionnaires, literature research and interviews, which then analyzed through path analysis with multivariate data techniques to examine the hypothesis.

\section{RESULTS AND DISCUSSION}

\section{Data Validity Test}

Based on the validity test, it was found that all indicators and research variables were declared valid (r-count $>$ r-table $=0.300$ ) and reliable (cronbach's alpha $>0.600$ ). 
Table 1. Value of Validity and Reliability

\begin{tabular}{|l|c|c|}
\hline \multicolumn{1}{|c|}{ Variable } & r-count & Cronbach's Alpha \\
\hline Social Media & $0.332-0.630$ & 0.835 \\
\hline Promotion & $0.392-0.696$ & 0.840 \\
\hline Purchase Decision & $0.508-0.704$ & 0.897 \\
\hline
\end{tabular}

Then, from the normality test through K-S Test, it was found that the significance value was greater than 0.200 , so it can be finalized that the data tested were normally distributed.

Table 2. Data Normality Test

One-Sample Kolmogorov-Smirnov Test

\begin{tabular}{llr} 
& & $\begin{array}{r}\text { Unstandardized } \\
\text { Residual }\end{array}$ \\
\hline $\mathrm{N}$ & & 175 \\
\hline Normal Parameters & & \multicolumn{1}{c}{, b } \\
& Mean & .0000000 \\
\cline { 2 - 3 } & Std. Deviation & 3.86002956 \\
\hline Most Extreme Differences & Absolute & .045 \\
\cline { 2 - 3 } & Positive & .043 \\
\cline { 2 - 3 } & Negative & -.045 \\
\hline Test Statistic & & .045 \\
\hline Asymp. Sig. (2-tailed) & & $.200^{\mathrm{c}, \mathrm{d}}$ \\
\hline
\end{tabular}

\section{Path Analysis}

Derived from the results of data processed, it shows that 1) The impact caused by Social Media variable (X) to Promotion (Y) was 0.180 or $18 \%$; 2) The influence from Social Media variable (X) on Purchase Decision (Z) was 0.015 or $1.5 \%$; and 3 ) the affect from the Promotion variable (Y) towards Purchase Decision $(\mathrm{Z})$ which is 0.244 or $24.4 \%$.

Table 3. Direct and Indirect Effect

\begin{tabular}{|c|c|c|c|}
\hline Variable & Interpretation Path Analysis & Estimation & Amount of Influence \\
\hline \multirow{3}{*}{ Social Media $(\mathrm{X})$} & Direct Effect on $Y$ & $0.412^{2}$ & 0.169 \\
\hline & Indirect Effect of $\mathrm{X}$ on $\mathrm{Y}$ & $0.060 \times 0.482 \times 0.412$ & 0.011 \\
\hline & \multicolumn{2}{|c|}{ Total } & 0.180 \\
\hline \multirow{3}{*}{ Social Media (X) } & Direct Effect on Z & $0.060^{2}$ & 0.004 \\
\hline & Indirect Effect of $X$ on $Z$ & $0.060 \times 0.482 \times 0.412$ & 0.011 \\
\hline & \multicolumn{2}{|c|}{ Total } & 0.015 \\
\hline \multirow{3}{*}{ Promotion $(\mathrm{Y})$} & Direct Effect on Z & $0.482^{2}$ & 0.233 \\
\hline & Indirect Effect of $Y$ on $Z$ & $0.060 \times 0.482 \times 0.412$ & 0.011 \\
\hline & \multicolumn{2}{|c|}{ Total } & 0.244 \\
\hline
\end{tabular}

\section{Hypothesis Test}

Established from the significance test outcomes, it appears that:

1) The value of sig. of $0.000<0.05$ and t count $5.940>t$-table 1.653 , so it can be presumed that social media has a positive affect on promotion.

2) The value of sig. of $0.431>0.05$ and $t$-count $0.790<\mathrm{t}$-table 1.653 , so its arranged that social media has no affect to purchase decisions. 
3) The value of sig. of $0.000<0.05$ and t-count $7.242>$ t-table 1.653 , so it can be concluded that promotion affects the purchase decisions.

4)

Table 4. Significance Test

\begin{tabular}{|c|c|c|c|c|c|}
\hline Structure & Sig. & $\alpha$ & t-count & t-table & Result \\
\hline$\rho Y X$ & 0.000 & 0.05 & 5.940 & 1.653 & $H_{a}$ Accepted \\
\hline$\rho Z X$ & 0.431 & 0.05 & 0.790 & 1.653 & $H_{a}$ Rejected \\
\hline$\rho Z Y$ & 0.000 & 0.05 & 7.242 & 1.653 & $H_{a}$ Accepted \\
\hline
\end{tabular}

\section{Discussion}

Developed from the research results on social media variables, it gained the total score of 9.317 and an average score of 621.13. Product recommendation indicator has the highest score with 637. It can be interpreted that other people's suggestion are greatly influence for eSenak consumers who will ultimately decide to purchase eSenak products. The lowest score was achieved by the share indicator with a score of 612. Though its the lowest score but still in the agree range, it can be concluded that consumer interaction in the form of shares on eSenak Karawang social media was still quite good in interactions which later became eSenak's insight. The path coefficient for the social media variable $(\mathrm{X})$ on promotion $(\mathrm{Y})$ was 0.412 . This shows that the coefficient of social media $(\mathrm{X})$ to promotion $(\mathrm{Y})$ is 0.412 . With the formula $\mathrm{CD}=\mathrm{r}^{2} \mathrm{x} 100 \%$. Drew from the coefficient of determination estimation, a value of $16.9 \%$ was obtained, which means that the value of promotion which affected by social media variables was $16.9 \%$.

Gleaned from the research results on promotion variables, the total score which obtained was 6,111 with the average 679.00. The delivery message indicator is the criterion with the highest score of 701. So it can be concluded that in conducting promotions through social media eSenak has succeeded in conveying the message to convinced the consumers. The lowest score was the promotion duration indicator with score of 655 though it is the lowest but the results are still quite good. So it can be finalized that the duration of eSenak promotion is quite good and easy to access or claim the use of existing promotions. The path coefficient for Social Media variable (X) on Purchase Decision (Z) was 0.060. This shows that the coefficient of Social Media (X) on Purchase Decision (Z) was 0.060. Through the formula $C D=r^{2} \times 100 \%$, the calculation results from the coefficient of determination has obtained a value of $0.4 \%$, which means that Purchase Decision was greatly influenced by the Social Media variable with amount of $0.4 \%$.

Based on the research result on purchase decision variables it was obtained a total score of 6.747 with an average of 674.70. Product completeness indicator is the highest indicator with a score of 686 . So it can be realized that consumers agreed with every ingredient that used by eSenak from basic ingredients to toppings so that reason why they agreed about it. It has the advantage is an indicator with the lowest score, which is only 647 . Though the lowest but still remain good compared to famous brands of similar drinks, maybe eSenak is still in the progress in pursuing levels to reach the same level of opportunities that famous brands has, By these results it can be said that eSenak consumers agreed if eSenak products have their own advantages on their products. Path coefficient for the Promotion variable (Y) to Purchase Decision $(\mathrm{Z})$ was 0.482 . This indicates that coefficient from the Promotion path (Y) 
on Purchase Decision $(Z)$ was 0.482 . Through these formula of $C D=r^{2} x 100 \%$, the calculation results from the coefficient of determination obtained a value of $23.2 \%$, meaning that Purchase Decision is affected by Promotion variable with $23.2 \%$.

\section{CONCLUSIONS AND RECOMMENDATION Conclusion}

In accordance with research that has been completed above, the conclusions that can be drawn as follows:

1) Social media has a positive affect on promotion.

2) Social media has no affect on purchase decisions.

3) Promotion affects the purchase decision.

\section{Recommendations}

Recommendations that can be advised by researchers relates to this research results are:

1) eSenak social media management were advised to create informative, educative, and interactive content through feed planning, copywriting, and more structured content Thus, consumers and eSenak followers will be able to interact with each other and add insight on eSenak Karawang social media.

2) eSenak management were advised to make more useful features on Instagram, particularly feeds and stories in order to marketing its new variants of products, the benefits of the materials that used, as well as the promotions offered, so as to increase insight on social media which impacting on increasing new consumers.

3) eSenak management were advised to make products which more innovative than competitors by considering it tastes, appearance and price so do with promotion.

4) The researcher hopes that for the next further research will be add another variables which have not been studied, such as Consumers satisfaction and product quality that highly affect purchase decisions in a wider research object.

\section{REFERENCE}

Armstrong, G., \& Kotler, P. (2013). Marketing An Introduction. New Jersey: Pearson Education, Inc.

Armstrong, G., Kotler, P., \& Opresnik, M. O. (2017). Marketing An Introduction. (13 ${ }^{\text {th }}$ Global Edition). England: Pearson Education Limited.

Dewi, A. M. (2018). Pengaruh Iklan Online Melalui Instagram Terhadap Keputusan Pembelian Bagi Peningkatan Penjualan Produk Kuliner Lokal. Jurnal Ekonomi Universitas Kadika, 3(1).

Diyatma, A., \& Rahayu, I. (2017). Pengaruh Promosi Melalui Media Sosial Instagram Terhadap Keputusan Pembelian Produk Saka Bistro \&bar. eProceedings of Management, 4(1).

Khoiro, F., Rachma, N., \& Hufron, M. (2019). PENGARUH PROMOSI MEDIA SOSIAL TERHADAP KEPUTUSAN PEMBELIAN DENGAN VIRAL MARKETTING SEBAGAI VARIABEL INTERVENING (STUDI PADA KONSUMEN WARUNG SIJI HOUSE AND RESTO MALANG). Jurnal Ilmiah Riset Manajemen, 8(13). 
Kotler, P., \& Keller, K. L. (2016). Marketing Management. (15 ${ }^{\text {th }}$ Global Edition). England: Pearson Education Limited.

Mileva, L., \& Fauzi DH, A. (2018). Pengaruh Social Media Marketing Terhadap Keputusan Pembelian (Survei Online pada Mahasiswa Sarjana Jurusan Ilmu Administrasi Bisnis Angkatan 2014/2015 Fakultas Ilmu Administrasi Universitas Brawijaya yang Membeli Starbucks Menggunakan LINE). Jurnal Administrasi Bisnis, 58(1), 181189.

Putra, D. A. (2020, Oktober 9). Menteri Teten: Rata-Rata Omzet UMKM Turun 70 Persen selama Pandemi. Liputan 6. https://www.liputan6.com/bisnis/read/4378240/menteriteten-rata-rata-omzet-umkm-turun-70-persen-selama-pandemi

Rina, R. (2020, April 8). Dihantam Corona, Produksi Industri Mamin Melorot 10-40\%. CNBC Indonesia. https://www.cnbcindonesia.com/news/20200408193750-4150721/dihantam-corona-produksi-industri-mamin-melorot-10-40

Solomon, M. R. (2018). Consumer Behavior Buying, Having, and Being. (Twelfth Edition). England: Pearson Education Limited.

Tjiptono, F. (2012). Riset Pemasaran. Yogyakarta: Andi Offset.

Tjiptono, F. (2015). Strategi Pemasaran, Edisi 4. Yogyakarta: CV. ANDI OFFSET. 